\title{
ELECTRICITY GENERATION FROM BIOMASS GASIFICATION
}

\author{
A. S. Rumão, \\ E. F. Jaguaribe ${ }^{a}$, \\ A. F. Bezerra ${ }^{a}$, \\ B. L. N. Oliveira ${ }^{a}$, \\ and B. L. C. Queiroga ${ }^{b}$ \\ ${ }^{a}$ Universidade Federal do Paraíba \\ Departamento de Engenharia Mecânica \\ Jardim Cidade Universitária \\ CEP. 58059-900, J. Pessoa, Paraíba, Brasil \\ adrianositonio@yahoo.com.br \\ bUniversidade Federal do Paraíba \\ Departamento de Eng. de Energias Renováveis \\ Jardim Cidade Universitária \\ CEP. 58059-900, J. Pessoa, Paraíba, Brasil. \\ Received: November 26, 2013 \\ Revised: December 10, 2013 \\ Accepted: January 10, 2014
}

ABSTRACT

Brazil is among the ten largest consumers of electricity in the world, and in the last decades its demand for electricity has been continuously increasing. As a consequence it has not been capable to ensure enough expansion of its electric power network, mostly affecting isolated communities. The present study discusses the use of a system formed by an Indian residue biomass gasifier and a $36 \mathrm{kVA}$ engine-generator, which should generate $20 \mathrm{kWe}$, using gas-alone mode engine. The engine was, originally, a MWM D229-4 diesel engine, which was converted into an Otto cycle to run only with producer gas. The system performance was evaluated for different engine's advance ignition angles, and two types of biomass. As the Indian gasifier was designed to operate just with dual-fuel mode to feed a gas-alone engine, some changes in the gasifier's water cleaning system were required. The modifications enabled the system to improve the power generation which overcame the $20 \mathrm{kWe}$ reaching $26 \mathrm{kWe}$. Technical and economic considerations showed that the bioelectricity based on bio-residual gasifier may be a viable and ecological option for regions having enough biomass residue and not served by the system network.

Key-words: Biomass gasifier; diesel engine conversion, electricity generation, wood wastes.

\section{NOMENCLATURE}

CT/UFPB - Technology Center of the Federal University of Paraiba

LI - Laboratory of Innovation

IISc/CGPL - Indian Institute of Science/Combustion Gas Propulsion Laboratory

IPT - Technological Research Institute of São Paulo

\section{INTRODUCTION}

Brazil is among the ten largest consumers of electricity in the world. Its demand continuously increases. In the past twelve years it has risen $38 \%$, while the percentage in the world average was just 30 (Fernandes, 2012). On the other hand, the primary energy consumption also has mounted significantly, demanding, in recent decades, huge efforts to increase the production of electricity, and to diversify the types of sources. Its condition of being selfsufficient in oil, however, has not been a guarantee of satisfaction of all the needs of a country in progress and with a rather large index of population enlargement. In turn, the Brazilian horizon, in terms of electricity, is not encouraging: the energy consumption rose in 2012 by $3.3 \%$, as compared to the previous year (Itaipu Binacional, 2013) and it is expected that in 2020 it will be $61 \%$ higher than in
2010 (Tolmasquim, 2012). In addition, all the electric power plants in operation produce just 129,174,669 $\mathrm{kW}$, where $89 \%$ comes from renewable sources, $74 \%$ of all originating from hydroelectric plants (BEN, 2012, BIG, 2013). Otherwise, the remaining available hydroelectric power is very committed to economic viability and for some regions there are restrictions related to environmental impact, making those investments costly.

The rapid increase in energy consumption prevents the expansion of the distribution network, directly affecting the isolated communities, not assisted by the basic grid network, victims of the lack of investments (Fall, 2000 ; McKendry, 2002; Torres et al, 1977). It is clear, however, that, as a compensation there is, generally, a great amount of biomass residue in those communities awaiting an appropriate technology to make profit of its energy content. In fact, the misuse of this available biomass leads to energy wasting, and deforestation, when, wood quite often illegally, is burnt inefficiently. A study by the Universidade Tecnológica Federal do Paraná concluded that if the rice husk of the entire rice production in Brazil were used, it would be possible to generate about $268.69 \mathrm{MW}$, i.e. $0.21 \%$ of the country's total energy production (Silva et al, 2012). Moreover, it should be pointed out that just the low cost of waste material combined with the reduction in environmental damage would be enough 
to make bioelectricity an excellent source of energy to supply electricity deficits.

The use of modern gasifiers with high gasification efficiency for nearly any kind of biomass to generate the producer gas, is indeed an extraordinary energy option that follows the global trend in the evolution of the use of gaseous fuels, mainly motivated by the possibility of the "decarbonisation of the economy" (Grübler, 1998, Nakicenovic, 1997), given that such fuels have small carbon chains. Thus, not only is the biomass gasification technology capable of turning the use of renewable fuels viable, but with the present technology it also ensures performances comparable to centralized power generation plants.

Conscious of the technical, social and ecological importance that the choice of solution in the quest for energy may have, the Laboratory of Innovation at CT/UFPB, LI, has elected biomass as the source of energy, since it is the major alternative resource of energy in Brazil. Therefore, the main goal of this study prepared at the LI, is to generate electricity using a system formed by a modern open top biomass gasifier, (having a water gas cleaning system) imported from the Indian Institute of Science/Combustion Gas Propulsion Laboratory, IISc/CGPL, see Figure 1, and a $36 \mathrm{kVA}$ enginegenerator. The engine, originally a Diesel MWM D229-4 was converted at the LI to run just with the producer gas, (see Figure 2), its original compression rate being kept, i.e. 17:1.

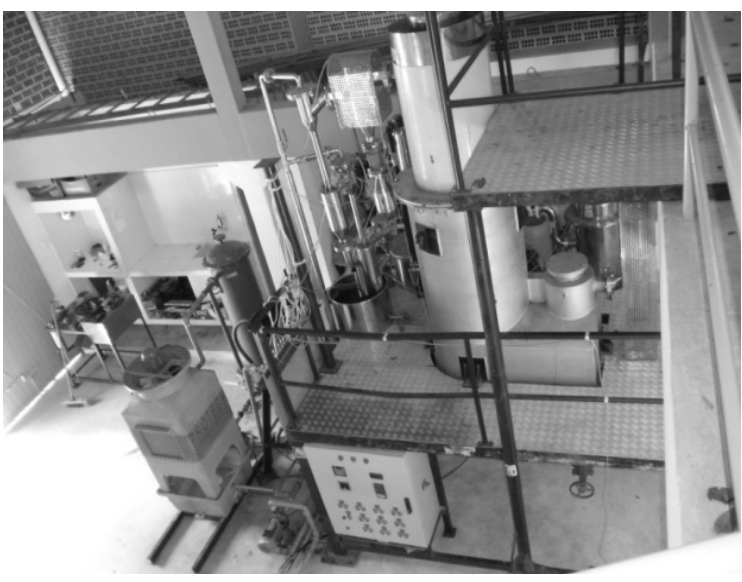

Figure 1. The imported open top biomass gasifier.

\section{MATERIALS AND METHODS}

Two types of standard woods having different specific weights were used. The first one was selected from a blend of different pieces of wood, having non-uniform densities, which was called mix wood. The second sample formed by particles having much uniform and higher densities was named dense wood. The moisture content and its density were determined from samples of the used biomass.

For the first tests the gasifier was kept in its original configuration and the engine of the genset was the converted one. The fact that the imported gasifier had been designed to feed a dual-fuel mode engine, to generate at the maximum $20 \mathrm{kWe}$, for power levels higher than $8.4 \mathrm{kWe}$ it did not run properly, with a gas-alone mode: there was a sudden interruption of the engine due to flooding of the gas cleaning water. Therefore, drastic changes were introduced at the original water gas cleaning system of the gasifier.

After the modifications new tests were carried out feeding the gasifier, at each occasion, with just one type of wood, either mix or dense, after setting up the engine with a different advance ignition angle $\left(22^{\circ}, 20^{\circ}, 16^{\circ}\right.$ or $\left.9^{\circ}\right)$.

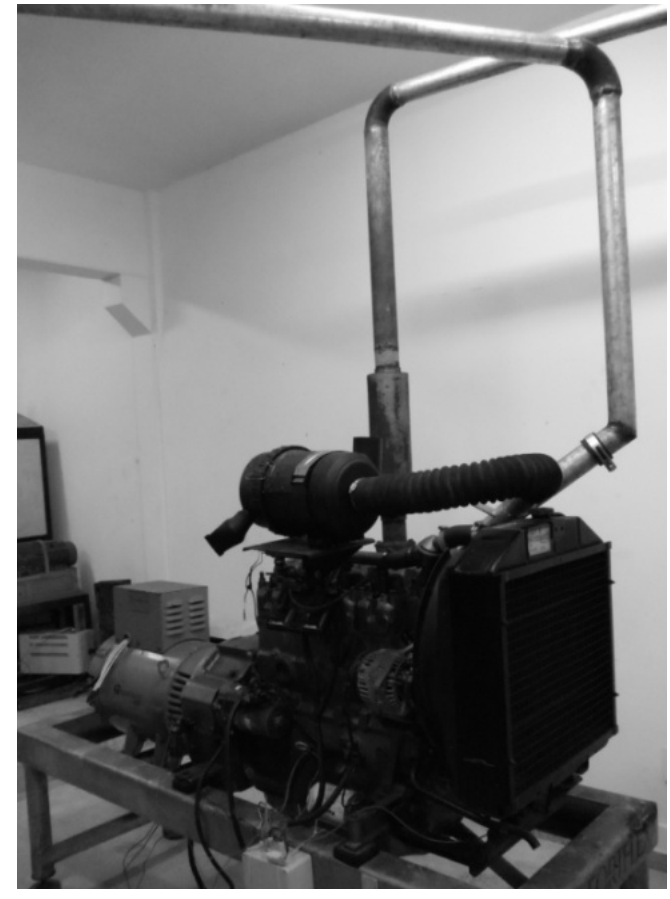

Figure 2. The converted Diesel MWM D229-4 engine into the Otto cycle.

\section{EXPERIMENTS}

In all the tests, with an average duration of 15 min, the gasifier was fueled with residue biomass (wood) having moisture content lower than $10.33 \%$, minimum density of $474,37 \mathrm{~kg} / \mathrm{m} 3$, and an average calorific value of $4.12 \mathrm{MJ} / \mathrm{Nm} 3$. At each test, for a fixed generated power $(\mathrm{kWe})$, the biomass consumption was evaluated $(\mathrm{kg} / \mathrm{h})$ using a scale and a stopwatch.

A flow balance air/producer gas controller apparatus to regulate the mixture air/gas was designed and built at the LI, (see Figure 3), and added to the converted engine. A system of a throttle body, a magnetic pickup, a central electron rotation and an electronic governor for controlling the maximum speed (1800 RPM) of the engine, were provided, as well. 


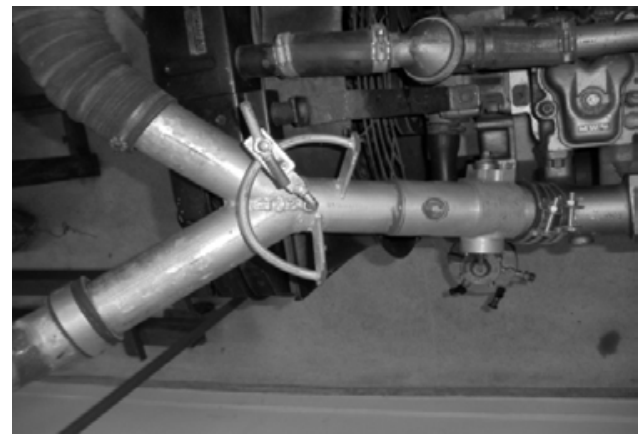

Figure 3. Flow balance Air/Producer Gas ratio control.

The producer gas flow was determined by a Pitot with U-tube manometer installed at a point situated before the engine intake manifold.

An electric dynamometer was used to evaluate the converted engine performances.

\section{RESULTS AND DISCUSSION}

The maximum power produced by the system composed of the original gasifier and the converted engine was $8.4 \mathrm{kWe}$, the advanced ignition angle set at $9^{\circ}$. As mentioned above, technical problems caused by overflowing of the gas cleaning water into the engine showed the need to alter the original water circuit design. After all the changes be accomplished, further tests were conducted using the following advance ignition angles: $22^{\circ}, 20^{\circ}, 16^{\circ}$ and $9^{\circ}$. The maximum output of $26 \mathrm{kWe}$ was achieved by using the producer gas and the advance ignition angle of $9^{\circ}$.

Figure 4 shows curves of the specific consumption of biomass in terms of the electrical power generated by the modified gasifier for different ignition angles, and two types of wood.

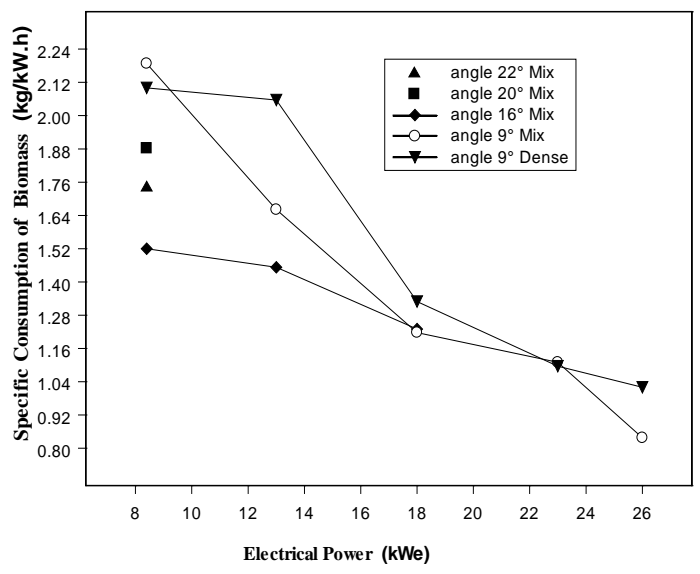

Figure 4. Specific consumption curves of mix and dense biomass of the modified gasifier, in terms of electrical powers produced by the generator for several advance ignition angles.

Figure 4 shows that the advance angle of $9^{\circ}$, regardless of the type of biomass, was the only one that gave rise to lower biomass consumption for the entire range of generated power. Taking into account powers up to $18 \mathrm{kWe}$, it is $16^{\circ}$ angle that best suits the economic condition. It is also seen that the lowest specific biomass consumption of $0.838 \mathrm{~kg} / \mathrm{kWe} . \mathrm{h}$, occurs for the maximum power value, i.e. $26 \mathrm{kWe}$, for dense wood, and advance ignition angle of $9^{\circ}$. At the Instituto de Pesquisas Tecnológicas de São Paulo, IPT, a system consisting of a similar gasifier operating a dual-fuel engine, having diesel replacement of about $75 \%$, generated $20 \mathrm{kWe}$, registering a higher biomass consumption, i.e. 0.900 kg/kWe.h (Apolinario, 2004, Martins, 2006).

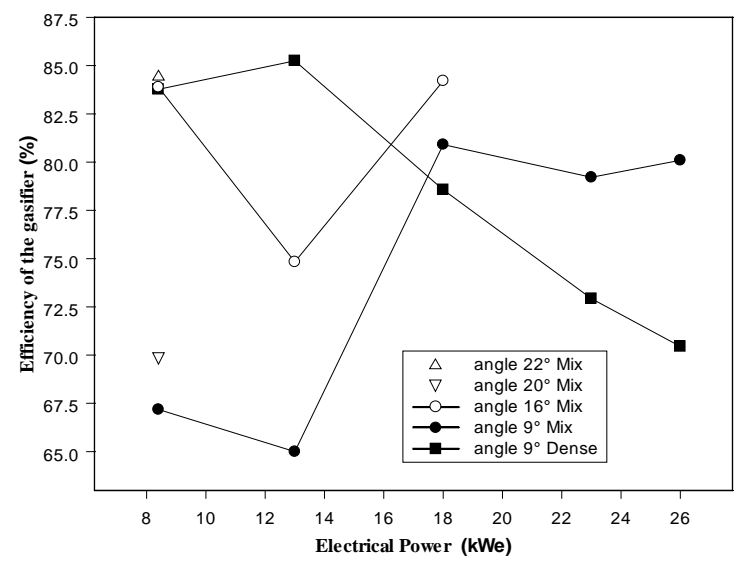

Figure 5. Efficiency of the modified gasifier in terms of the generated electrical power.

In Figure 5, the values of the efficiency for the modified gasifier are presented, in terms of the generated electrical power.

According to Figure 5 the efficiency of the gasifier depends on both the advance ignition angle, and the biomass type. The highest efficiency set down was $85.25 \%$, using dense biomass, and the advance ignition angle of $9^{\circ}$. Reed and Das (1988), points out that the percentage of a gasification process to convert the biomass energy into the gas energy varies from $60 \%$ to $90 \%$. At IPT, the highest recorded efficiency for the Indian gasifier of the same type, operating a dual-fuel mode was $72 \%$. In this case, the diesel replacement was $75 \%$ and the generated electric power was $20 \mathrm{kWe}$. (Apolinário, 2004, Martins , 2006). In India, at the IISc/CGPL, a similar gasifier working under the same conditions showed a maximum efficiency of 79 \% (Dasappa et al, 2003).

\section{CONCLUSION}

Based on the discussions and results above, we can conclude that:

1) The advance ignition angle adjustment is crucial for the performance of the converted Otto cycle engine, chiefly when operating a $100 \%$ producer gas fuelled engines, also influencing the 
efficiency of the gasifier.

2) There is a positive correlation between the engine advance ignition angle and the biomass gasifier consumption. For larger angles there was a reduction in consumption; however, there occurred a limitation in the maximum generated electrical power.

3) The type of biomass waste used to feed the gasifier is directly related to gasifier efficiency.

4) The system formed by the modified gasifier and the engine-generator discussed in the present study, showed better performance in generating electrical power, with lower specific biomass consumption, than the mentioned IPT and CGPL systems. (It should be pointed out that the diesel employed in the dual-fuel mode engine has a calorific value, almost, nine times the one of the producer gas.).

5) The fact that our system overcame in $6 \mathrm{kWe}$ the maximum electrical power originally indicated by its designers and constructors from the IISc, demonstrates that the main goal of the LI was achieved, that is, to master the concept of generating electrical energy from producer gas, using its own technique to convert Diesel engines into Otto cycle engines. It may be a first step in the direction of using these modern gasifiers to produce electricity in Brazil, in an economic and ecologically correct way.

\section{REFERENCE}

Apolinario, S. M., 2004, Tecnologia de Gaseificação de Biomassa: Projetos Gaseifamaz e Gaseibras, in: $1^{\circ}$ Seminário sobre a Utilização de Energias Renováveis para Eletrificação Rural do Norte e Nordeste do Brasil, CENBIO, Brasília. (in Portuguese)

BEN - Balanço Energético Nacional, 2012, Ministério de Minas e Energia. (in Portuguese)

BIG -Banco de Informações de Geração, 2013, Capacidade de Geração do Brasil, ANEEL. (in Portuguese)

Dasappa, S., Mukunda, H. S., Paul, P. J., and Rajan, N. K. S., 2003, Biomass to Energy: the Science and Technology of the IISc Bio-energy systems, 1ed. Ídia, ABETS.

Fall, L. M., 2000, L’Énergie Rurale et la Pauvreté Dans les Pays en Délevoppement Revue de l’Énergie, No. 522, pp. 603-628.

Fernandes, D., 2012, Brasil é $10^{\circ}$ Maior Consumidor Mundial de Energia Elétrica, BBC_Brasil. (in Portuguese)

Grübler, A., 1998, Technologyand Global Change, Cambridge, Cambridge - University Press.

Itaipu Binacional, 2013, Agora é Oficial: Itaipu fecha 2012 com um total de 98.287.128 MWh, Sala de Imprensa. (in Portuguese)

Martins, O. S., 2006, Gaseificação de Biomassa, Transferência de Tecnologia - Projeto
Indiano, Projeto GASEIFAMAZ, CENBIO. (in Portuguese)

Mckendry, P., 2002, Energy Production from Biomass, Bioresource Technology, Vol. 83, pp. 3746.

Nakicenovic, N., 1997, Freeing Energy from Carbon, Dans Technological Trajectories and the Human Environment, Washington, National Academy Press, pp. 74-88.

Reed, T. B., and Das, A., 1988, Handbook of Biomass Downdraft Gasifier Engine Systems, Biomass Energy Foundation Press, USA.

Silva, O. H. da, Ardenghi, T. C., Ritter, C. M., Santos, F. da R., and Halmeman, M. C. R., 2012, Potencial Energético da Biomassa da Casca do Arroz no Brasil, in: III SIAUT - Simpósio Ambiental da Universidade Tecnológica Federal do Paraná. Campo Mourão, Paraná. (in Portuguese)

Tolmasquim, M. T., 2012, Perspectivas e Planejamento do Setor Energético no Brasil, Scielo Brasil, Vol. 26, No. 74, pp. 247-260. (in Portuguese)

Torres, C. C., Cheema, L. S., and Lobo, P. C., 1977, Prospects of Power Generation from Solar Plants in the Northeast of Brazil, Solar Energy Symposium, No. 477, pp. 581-590. 